\title{
Percutaneous retrieval of complicated intravascular devices
}

\begin{abstract}
Background: Cardiac catheterization procedures are sometimes associated with unanticipated serious complications related to intravascular devices (IVD) which include embolization, displacement, knotting, entrapment etc. Percutaneous management is difficult and may even warrant surgical extraction. We evaluated clinical profile, causes, management and outcomes of percutaneous retrieval of such complicated IVD

Methods and Findings: In this retrospective, single-center study, medical and procedural records of all patients who had undergone percutaneous retrieval of complicated IVD using combination of guide catheters and snares between January 2013 and January 2018 were examined. A total of 11 patients with complicated IVD were diagnosed, with mean age of $48.27 \pm 15$ years. Eight $(72.7 \%)$ patients were asymptomatic, while three $(27.3 \%)$ patients had clinical findings including hematuria, hypotension and bradyarrhythmia. Complicated IVD involved were central venous pressure guide wires in four (36.4\%), coronary stents in two (18.2\%) and patent ductus arteriosus closure device, atrial septal defect closure device, ventricular septal defect closure device, temporary pacing lead and $0.035^{\prime \prime}$ guidewire each in one case. Probable mechanisms that could have led to complications were loss of control in five (45.5\%), migration due to incorrect deployment in two (18.2\%), migration due to complex coronary anatomy in two (18.2\%), blind insertion without fluoroscopy in one $(9.1 \%)$, and incorrect sizing or device malfunction in one $(9.1 \%)$ case. Percutaneous retrieval was successful in $10(90.9 \%)$ patients, while one $(9.1 \%)$ patient with migrated coronary stent required opensurgical retrieval. There were no procedure-related complications.

Conclusions: Patients with complicated IVD, warranting retrieval, may have variable clinical presentation and multifactorial causes. Percutaneous retrieval of such devices has a higher success rate with minimal complications.
\end{abstract}

Keywords: Catheterization; Intravascular devices; Percutaneous; Retrieval; Snare

\section{Introduction}

The exponentially increasing cardiac catheterization procedures involving intravascular devices (IVD) are sometimes associated with unanticipated serious complications like embolization, displacement, knotting, entrapment, or device fragmentation. Since presence of such complicated IVD in a patient may cause life threatening consequences, it warrants immediate surgical or percutaneous retrieval. In 1964, Thomas et al. for the first time reported non-surgical retrieval of migrated steel spring from right atrium and inferior vena cava (IVC) using bronchoscopic forceps [1]. Since then, retrieval reports of various IVD have been published including devices like catheter fragments, guidewires, pacemaker wires, stents, embolization coils, sheaths, closure devices, IVC filters etc. [2]. The clinical presentation of such complicated IVD is variable and can sometimes be even fatal. Percutaneous retrieval could be technically challenging in these cases. However, various retrieval devices like snares, Dormia baskets, biopsy forceps, tip-deflecting wires, pincher devices, oversized sheaths or balloon catheters can help [3]. Various studies evaluating the success of IVD retrieval using these devices have been published in intervention cardiology and radiology literature [3-11]; nevertheless, very few studies have been published from India. In this milieu, we performed a retrospective, single center study to share our experience of percutaneous retrieval of such complicated IVD at our teaching institute from India.
Jaywant Nawale, Ajay Chaurasia, Digvijay Nalawade*, Sandeep Kamat, Meghav Shah

Department of Cardiology, TNMC \& BYL Nair Ch. Hospital, Mumbai, Maharashtra, India

*Author for Correspondence:

Digvijay Nalawade

Tel.: +91-22-23027610

E-mail: nalawadedigu@gmail.com

Received date: Dec 03, 2018

Accepted date: Jan 20, 2019

Publication date: Jan 25, 2019 


\section{Subjects and Methods}

\section{Study design and patient selection}

This was a retrospective, single center study. All patients who had undergone percutaneous retrieval of complicated IVD using combination of guide catheters and snares during the study period of five years (January 2013 to January 2018) were retrospectively reviewed. There were no other exclusion criteria. All patients provided informed consent for the procedure and subsequent data collection and analysis for the research purposes and the procedures followed were in accordance with the institutional ethical committee standards. Accordingly, 11 patients were recruited. Of them, six patients had IVD complications in our department while five patients were referred by other departments or hospitals.

\section{Data collection}

The medical and procedural records of recruited patients were reviewed in terms of demographic details, clinical presentation, comorbidities, information about complicated IVD, probable mechanisms or causes, management and outcomes.

\section{Percutaneous retrieval procedure}

In patients with intra-procedural complications, percutaneous retrieval was attempted immediately after recognition in the same session. In patients with incidentally diagnosed complicated IVD, percutaneous retrieval was performed within 12 hours of discovery.

Removal of IVD was performed using standard vascular sheaths $(6-10 \mathrm{~F})$ with transfemoral (artery or vein) approach in majority of cases (Table 1 ). Few cases required additional contralateral femoral (artery or vein) access and few cases with large sized IVD (closure devices and knotted pacemaker lead) required oversized long sheaths. Combination of guide catheters and different types of snares (Table 1) were used for retrieval, which include nitinol gooseneck loop macro/ microsnare, triple looped snare, and needles eye snare. Snare was sized according to the chamber or vessel containing the complicated IVD. Due to lack of standard retrieval algorithms, the type of snare used was up to the discretion of treating experienced cardiologist. A guide catheter (6 F Judkin's right, Amplatz right or multipurpose catheter) along with snare loop was placed close to the IVD, which was then encircled with the loop and the guide catheter was advanced over the snare to close its loop.
Subsequently, the entire assembly with grasped IVD was pulled out. No venotomy was required. All patients were observed in ICU for a day after the procedure.

\section{Study endpoints}

Procedural success was evaluated as primary endpoint of the study, while clinical success was evaluated as safety endpoint. Here, procedural success was defined as successful retrieval of complicated IVD by percutaneous methods using any retrieval device. Clinical success was defined as procedural success without occurrence of any clinically significant events.

\section{Statistical analysis}

Statistical analysis was performed using Statistical Package for Social Sciences (SPSS), version 16.0 software (SPSS Inc., Chicago, IL, USA). Continuous variables are presented as mean \pm standard deviation, whereas categorical variables are expressed as percentages.

\section{Results}

\section{Clinical presentation}

Of 11 patients diagnosed with complicated IVD, six $(55.5 \%)$ were males and five $(45.5 \%)$ were females. The mean age was $48.27 \pm 15$ years (age range: 25 to 71 years). Of these patients, eight $(72.7 \%)$ patients were asymptomatic who were diagnosed either incidentally or as an intra-procedural complication. Three $(27.3 \%)$ patients had clinical findings including hematuria, hypotension and bradyarrythmia (Table 1 ).

\section{IVD involved and its location}

Of complicated IVDs (Table 1)., there were four (36.4\%) cases of central venous pressure (CVP) guide wires (Figures 1a-1c), two (18.2\%) cases of coronary stents, and one $(9.1 \%)$ case each of patent ductus arteriosus (PDA) closure device (Figures 1d-1f), atrial septal defect (ASD) closure device, ventricular septal defect (VSD) closure device, temporary pacing lead and 0.035" guidewire (Figures 1g-1i). These complicated IVDs were located in the right heart in three $(27.3 \%)$ cases, superior vena cava in two (18.2\%) cases, femoral artery in two $(18.2 \%)$ cases and one (9.1\%) case each in inferior vena cava, descending thoracic aorta, left main coronary ostium and PDA (Table 1). 


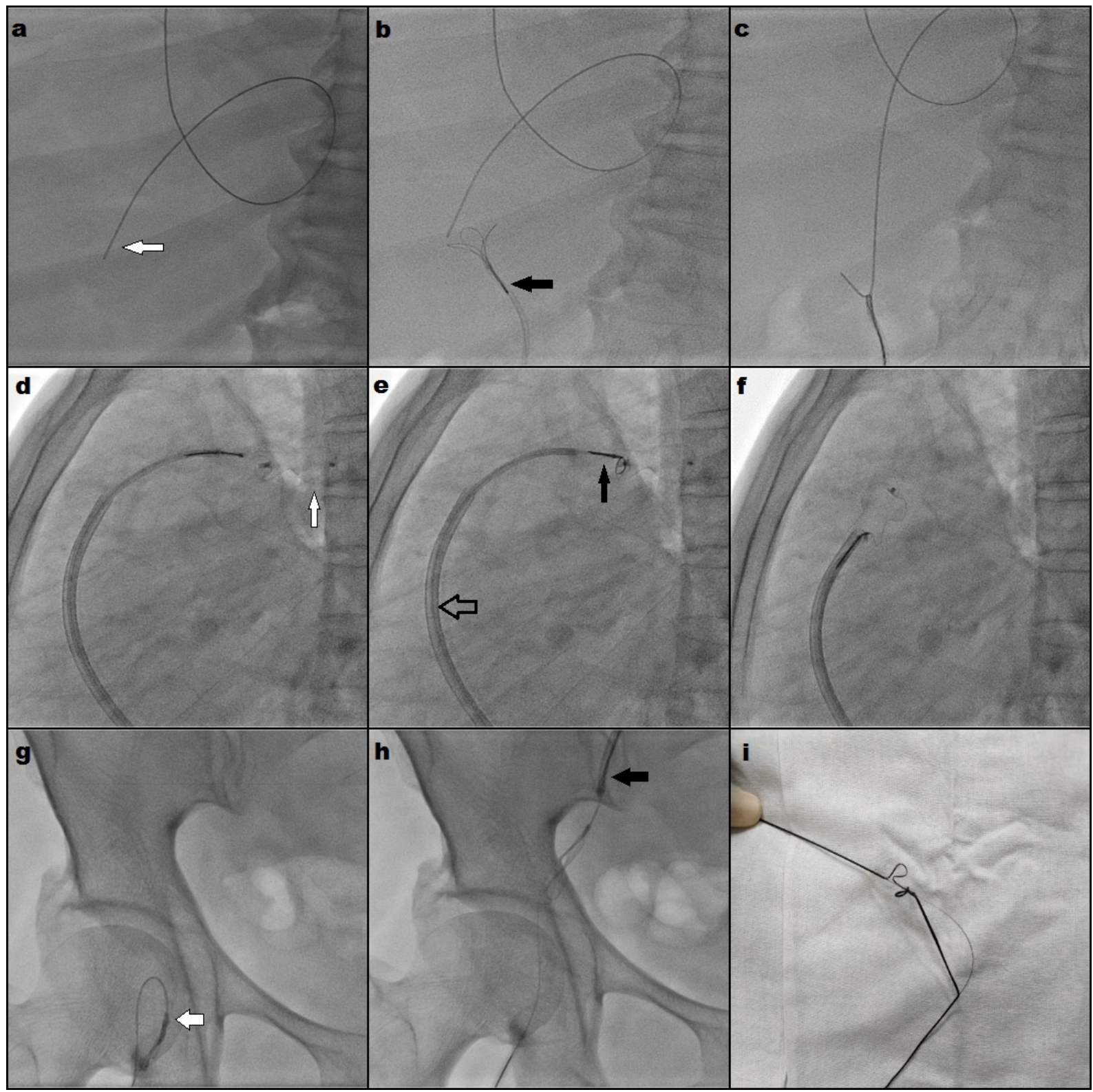

Figure 1: Images of percutaneous retrieved intravascular devices: (A) Cine fluoroscopic image of central venous pressure guidewire (white arrowhead) with its free edge lying in inferior vena cava; (B) Cine fluoroscopic image showing triple looped snare (black arrowhead) along with guide catheter approaching the free edge of central venous pressure guidewire; (C) Cine fluoroscopic image showing successfully snared central venous pressure guidewire; (D) Cine fluoroscopic image of malformed in situ patent ductus arteriosus closure device with mushroom shaped aortic retention skirt (white arrowhead); (E) Cine fluoroscopic image showing microsnare (black arrowhead) encircling the knob on pulmonary end of patent ductus arteriosus closure device along with guide catheter and long sheath (empty arrowhead); (F) Cine fluoroscopic image showing successfully snared patent ductus arteriosus closure device; (G) Cine fluoroscopic image of 0.035 " polymer coated guidewire (white arrowhead) with distal coiled part lying in femoral artery and adjacent subcutaneous tissue; $(\mathrm{H})$ Cine fluoroscopic image showing successfully snared $0.035^{\prime \prime}$ polymer coated guidewire with angled loop macrosnare (black arrowhead); (I) Photograph of retrieved 0.035" polymer coated guidewire.

\section{Clinical indication and mechanisms of complication}

The indications of retrieval were misplacements in eight $(72.7 \%)$, knotting in two $(18.2 \%)$, and malpositioning in one $(9.1 \%)$ case. The probable mechanisms that could have led to complications were loss of control in five $(45.5 \%)$, migration due to incorrect deployment in two (18.2\%), migration due to complex coronary anatomy in two $(18.2 \%)$, blind insertion without fluoroscopy in one $(9.1 \%)$ and incorrect sizing or device malfunction in one $(9.1 \%)$ case (Table 1).

Table 1: Clinical characteristics, management and outcomes of percutaneous retrieval of complicated IVD 


\begin{tabular}{|c|c|c|c|c|c|c|c|c|c|c|c|}
\hline No. & $\begin{array}{l}\text { Age/ } \\
\text { Sex }\end{array}$ & $\begin{array}{l}\text { Patient } \\
\text { status }\end{array}$ & $\begin{array}{l}\text { Vascular } \\
\text { approach }\end{array}$ & $\begin{array}{l}\text { Type of } \\
\text { IVD }\end{array}$ & $\begin{array}{l}\text { Site of } \\
\text { IVD }\end{array}$ & \begin{tabular}{|l|} 
Clinical \\
presenta \\
tion
\end{tabular} & $\begin{array}{l}\text { Indications } \\
\text { for } \\
\text { retrieval }\end{array}$ & $\begin{array}{l}\text { Probable mechanism/ } \\
\text { cause of complication }\end{array}$ & $\begin{array}{l}\text { Retrieval } \\
\text { device }\end{array}$ & $\begin{array}{l}\text { Clinical } \\
\text { success }\end{array}$ & $\begin{array}{l}\text { Compl } \\
\text { ications }\end{array}$ \\
\hline 1 & $30 / F$ & 1 & Fma & $\begin{array}{l}\text { PDA } \\
\text { closure } \\
\text { device }\end{array}$ & PDA & Hematuria & Malposition & $\begin{array}{l}\text { Incorrect size or device } \\
\text { malfunction }\end{array}$ & $\begin{array}{l}\text { Microsn } \\
\text { are\# }\end{array}$ & $\mathrm{Y}$ & $\mathrm{N}$ \\
\hline 2 & $27 / F$ & 1 & Fma & $\begin{array}{l}\text { VSD } \\
\text { closure } \\
\text { device }\end{array}$ & DTA & $\begin{array}{l}\text { Hypoten } \\
\text { sion }\end{array}$ & Misplaced & $\begin{array}{l}\text { Migration due to incorrect } \\
\text { deployment }\end{array}$ & $\begin{array}{l}\text { Loop } \\
\text { snare* }^{*}\end{array}$ & $\mathrm{Y}$ & $N$ \\
\hline 3 & $25 / F$ & 1 & Fmv & $\begin{array}{l}\text { ASD } \\
\text { closure } \\
\text { device }\end{array}$ & RA & $\begin{array}{l}\text { Asympt } \\
\text { omatic }\end{array}$ & Misplaced & $\begin{array}{l}\text { Migration due to incorrect } \\
\text { deployment }\end{array}$ & $\begin{array}{l}\text { Loop } \\
\text { snare* }^{*}\end{array}$ & $\mathrm{Y}$ & $N$ \\
\hline 4 & $45 / \mathrm{M}$ & $\mathrm{R}$ & $\begin{array}{l}\text { Fmv }+ \\
\text { CFmv }\end{array}$ & $\begin{array}{l}\text { Pacema } \\
\text { ker lead }\end{array}$ & SVC & $\begin{array}{l}\text { Loss of } \\
\text { pacing }\end{array}$ & Knotting & $\begin{array}{l}\text { Blind lead insertion } \\
\text { without fluoroscopy }\end{array}$ & $\begin{array}{l}\text { Needles } \\
\text { eyesnar } \\
\mathrm{e}\end{array}$ & $Y$ & $N$ \\
\hline 5 & $49 / \mathrm{M}$ & $\mathrm{R}$ & Fmv & CVP & IVC & $\begin{array}{l}\text { Asympt } \\
\text { omatic }\end{array}$ & Misplaced & Loss of control & $\begin{array}{l}\text { Triple } \\
\text { looped } \\
\text { snare\$ }\end{array}$ & $\mathrm{Y}$ & $\mathrm{N}$ \\
\hline 6 & $71 / F$ & $\mathrm{R}$ & Fmv & CVP & SVC & $\begin{array}{l}\text { Asympt } \\
\text { omatic }\end{array}$ & Misplaced & Loss of control & $\begin{array}{l}\text { Triple } \\
\text { looped } \\
\text { snare\$ }\end{array}$ & $Y$ & $N$ \\
\hline 7 & $57 / M$ & $\mathrm{R}$ & Fmv & CVP & RA & $\begin{array}{l}\text { Asympt } \\
\text { omatic }\end{array}$ & Misplaced & Loss of control & $\begin{array}{l}\text { Triple } \\
\text { looped } \\
\text { snare\$ }\end{array}$ & $\mathrm{Y}$ & $\mathrm{N}$ \\
\hline 8 & $63 / \mathrm{M}$ & $\mathrm{R}$ & Fmv & CVP & RA & $\begin{array}{l}\text { Asympt } \\
\text { omatic }\end{array}$ & Misplaced & Loss of control & $\begin{array}{l}\text { Triple } \\
\text { looped } \\
\text { snare\$ }\end{array}$ & $\mathrm{Y}$ & $\mathrm{N}$ \\
\hline 9 & $54 / \mathrm{M}$ & 1 & Fma & $\begin{array}{l}\text { Coronary } \\
\text { stent }\end{array}$ & $\begin{array}{l}\text { LMCA- } \\
\text { Aorta }\end{array}$ & $\begin{array}{l}\text { Asympt } \\
\text { omatic }\end{array}$ & Misplaced & $\begin{array}{l}\text { Migration due to calcified } \\
\text { tight coronary lesions } \\
\text { with proximal acute } \\
\text { angulation }\end{array}$ & $\begin{array}{l}\text { Microsn } \\
\text { are\# }\end{array}$ & $\mathrm{N}$ & $\mathrm{N}$ \\
\hline 10 & $61 / \mathrm{M}$ & 1 & $\begin{array}{l}\text { Fma }+ \\
\text { CFma }\end{array}$ & $\begin{array}{l}\text { Coronary } \\
\text { stent }\end{array}$ & $\begin{array}{l}\text { Femor } \\
\text { al } \\
\text { Artery }\end{array}$ & $\begin{array}{l}\text { Asympt } \\
\text { omatic }\end{array}$ & Misplaced & $\begin{array}{l}\text { Migration due to calcified } \\
\text { tight coronary lesions } \\
\text { with proximal acute } \\
\text { angulation }\end{array}$ & $\begin{array}{l}\text { Triple } \\
\text { looped } \\
\text { snare\$ }\end{array}$ & $Y$ & $N$ \\
\hline 11 & $49 / F$ & 1 & $\begin{array}{l}\text { Fma }+ \\
\text { CFma }\end{array}$ & $\begin{array}{l}0.035^{\prime \prime} \\
\text { guidewi } \\
\text { re }\end{array}$ & $\begin{array}{l}\text { Femor } \\
\text { al } \\
\text { Artery }\end{array}$ & $\begin{array}{l}\text { Asympt } \\
\text { omatic }\end{array}$ & Knotting & Loss of control & $\begin{array}{l}\text { Loop } \\
\text { snare }^{*}\end{array}$ & $Y$ & $N$ \\
\hline
\end{tabular}

[ASD-atrial septal defect, CVP-central venous pressure guide wire, CFma- contralateral femoral artery, CFmv- contralateral femoral vein, DTA-descending thoracic aorta,F-female Fma-femoral artery, Fmv- femoral vein,I-Inhouse patient, IVC-inferior venacava, IVDintravascular device, LMCA-left main coronary artery,M-male, N-no, PDA-patent ductus arteriosus, R- referred patient, RA-right atrium, SVC-superior vencava,VSD ventricular septal defect, Y-yes, * - nitinol angled loop macrosnare \# - nitinol $90^{\circ}$ angled loop microsnare, \$- nitinol triple looped snare]

\section{Management and Outcomes}

The vascular access and the retrieval device used in each case are presented in Table 1. Percutaneous retrieval was successful in $10(90.9 \%)$ patients. One (9.1\%) patient with coronary stent migrated at left main coronary ostium, required open surgical retrieval. There were no procedure related complications in any case.

\section{Discussion}

\section{Clinical characteristics}

With advancements in the field of interventions, the use of various IVD has increased and so have the chances of complications leading to retained foreign bodies. Such incidences of complicated IVD are reported in about $0.1 \%-0.8 \%$ cases of coronary interventions [12]. The clinical presentation of such patients is variable and depends on the site of 
complicated IVD and its further consequences. In our study, majority of patients $(72.7 \%)$ were clinically asymptomatic and were diagnosed incidentally or as an intra-procedural event, which is also consistent with previous larger studies (Table 2). The need for retrieval in such cases is to prevent further complications like infections, thrombosis, ischemia, and perforation. The rate of serious complications associated with untreated foreign body embolism has been reported to be as high as $71 \%$ [13], with a mortality rate in the range of
24\%-60\% [14,15]. In particular, patients with cardiopulmonary localization of foreign bodies are at risk for severe complications, ranging from cardiac arrhythmias to perforation [3,5]. We found three patients with clinical consequences in the form of hematuria which developed on second day of a PDA device closure with residual leak, hypotension which developed within few minutes in a case of migrated VSD device and bradyarrhythmia in a referred case of knotted temporary pacing lead.

Table 2: Studies with percutaneous retrieval for different types of complicated intravascular devices/foreign bodies (since year 2000 with more than 10 patients)

\begin{tabular}{|c|c|c|c|c|c|c|}
\hline $\begin{array}{l}\text { Study } \\
\text { (Publication } \\
\text { year) }\end{array}$ & $\begin{array}{l}\text { Total } \\
\text { number } \\
\text { of } \\
\text { patients } \\
\text { in study }\end{array}$ & $\begin{array}{l}\text { Number of } \\
\text { foreign } \\
\text { bodies } \\
\text { attempted } \\
\text { percutaneous } \\
\text { retrieval } \\
\text { alone }\end{array}$ & Clinical presentation $\mathbf{n}(\%)$ & $\begin{array}{l}\text { Retrieval devices } \\
\text { used }(\%)\end{array}$ & \multicolumn{2}{|c|}{ Outcomes } \\
\hline Koseoglu [3] & 15 & 15 & - & $\begin{array}{l}\text { Gooseneck loop } \\
\text { snare with } \\
\text { multipurpose } \\
\text { catheters }\end{array}$ & $15(100)$ & 0 \\
\hline Sheth [5] & 26 & 26 & - & $\begin{array}{l}\text { Dormia } \text { basket } \\
\text { with } \\
\text { catheters }\end{array}$ & $26(100)$ & 0 \\
\hline Wolf [6] & 78 & 78 & - & $\begin{array}{ll}\text { Gooseneck loop } \\
\text { snare(91); loop } \\
\text { snare } & \text { and } \\
\text { sidewinder } & \\
\text { catheter(8); } \\
\text { sidewinder } \\
\text { catheter(1); }\end{array}$ & $\begin{array}{l}68 \\
(87.2 \%)\end{array}$ & $\begin{array}{l}5 \quad(6.4 \%) \\
\text { Bradycardia, } 1- \\
\text { extrasystoles and } \\
\text { hypertension,2- } \\
\text { wrong vascular } \\
\text { access 1-sheath } \\
\text { dislocation) }\end{array}$ \\
\hline Bonvini [7] & 22 & 22 & $\begin{array}{lr}1 \text { (0.5)-ventricular arrhythmias; } 21 \\
\text { (95.5)-asymptomatic; } & (11- \\
\text { incidental } & \text { finding, } 10- \\
\text { intraprocedural complication) }\end{array}$ & $\begin{array}{l}\text { Triple-looped } \\
\text { snare }\end{array}$ & $21(95.5)$ & 0 \\
\hline Motta [8] & 12 & 12 & & $\begin{array}{l}\text { Loop } \\
\text { snare(83.3); } \\
\text { stone basket }\end{array}$ & $12(100)$ & $\begin{array}{l}1(8.33) \quad \text { (atrial } \\
\text { fibrillation) }\end{array}$ \\
\hline Cahill [9] & 18 & 19 & $\begin{array}{l}\text { 18(100)-asymptomatic } \\
\text { incidental finding; } \\
\text { intraprocedural complication) }\end{array}$ & $\begin{array}{l}\text { Loop snare; } \\
\text { Triple-looped } \\
\text { snare }\end{array}$ & $17(89.5)$ & 0 \\
\hline Carrol [10] & 26 & 24 & $\begin{array}{l}\text { 20(76.9)-asymptomatic; } 6(22.2)- \\
\text { symptomatic (1-chest pain due to } \\
\text { myocardial infraction; } 1 \text {-flank pain } \\
\text { due to retroperitoneal hematoma; }\end{array}$ & \begin{tabular}{lr}
\multicolumn{3}{c}{ Gooseneck loop } \\
snare; & Triple- \\
looped & snare; \\
Balloon & \\
catheters &
\end{tabular} & $19(79.2)$ & $\begin{array}{l}1(4.2) \text { (pulmonary } \\
\text { embolism) }\end{array}$ \\
\hline
\end{tabular}




\begin{tabular}{|l|l|l|l|l|l|l|}
\hline & & $\begin{array}{l}\text { 2- abdominal pain;2-abnormal } \\
\text { physical findings) }\end{array}$ & & \\
\hline $\begin{array}{l}\text { BaltazaresLipp } \\
{[11]}\end{array}$ & 13 & 13 & - & $\begin{array}{l}\text { Gooseneck loop } \\
\text { snare }\end{array}$ & $11(84.6)$ & 0 \\
\hline
\end{tabular}

\section{Probable Mechanisms or causes:}

Complications of IVD can be caused due to multiple factors related to procedure (technical), device or patient [10]. Of these, the procedure-related technical factors such as loss of control, incorrect deployment, blind insertion without fluoroscopy and incorrect sizing were most common in our study, which was similar to study by Carroll et al. [10]. Out of five cases in loss of control category, four were CVP guide wires and one 0.035 " hydrophilic guidewire. As per literature, loss of guidewire is either due to forceful insertion against resistance leading to its entrapment in distal tissues [2] or due to inadequate tension or insecure holding during insertion of CVP line [16]. Incorrect deployment was considered as the cause of migration in two cases of closure devices wherein the same devices were redeployed after their percutaneous retrieval. In one case of unusual knotting of temporary pacing lead, blind insertion without fluoroscopy was suspected as the probable cause [17].

Device related factors can also lead to complications. One patient with PDA closure device developed hematuria associated with hemolysis due to residual leak diagnosed on 2D-echocardiography. Device malfunction or incorrect sizing were considered as probable mechanisms in this case based on fluoroscopy which revealed a malformed mushroom shaped retention skirt (Figure 1d) and resolution of hemolysis which occurred after percutaneous retrieval of deformed device and PDA reclosure with higher sized device. According to Fatehi et al., this typical shape of deformed occluder occurs whenever an optimum positioning is not obtained due to incorrect size and the device is under tension, which causes ballooning of its aortic side and should further alert of potential complications [18].

In two cases with intra-procedural stent migration, patient-related factor in the form of complex coronary anatomy (Table 1) was considered as the predominant mechanism. Intra-procedural stent migration or displacements occur during pull back of a nondeployed stent-balloon assembly into the guide catheter, especially during interventions to extremely angulated and severely calcified coronary lesions [19-21]. It can also occur during stent deployment across an inadequately predilated lesion or in presence of tortuous vessels.

\section{Management and outcomes}

Depending on type and site of IVD, various percutaneous retrieval techniques and devices have been used in previous larger studies (Table 2). Of these, loop snare catheters are most commonly preferred which come in various sizes and shapes. According to review by Schechter et al., loop snares are currently the mainstay for endovascular retrieval with literature showing only $8.7 \%$ of foreign body retrieval with a device other than a snare [22]. These snare devices are made up of nitinol (nickel-titanium alloy), which confers flexibility, kink resistance and shape memory properties. Loop snare consists of single loop with around $90^{\circ}$ angle (gooseneck) with the shaft which increases the ease of capturing the device [3]. Microsnares (2-7 $\mathrm{mm}$ diameter) are used in coronaries while macrosnares $(5-35 \mathrm{~mm}$ diameter) are used in peripheral vessels and larger chambers [23]. Triplelooped snare (Figure 1b) has three inter-woven nitinol loops providing additional three dimensional coverage as compared to single loop snares $[7,23]$. Majority of the IVD in our study were retrieved using these two types of snares (Table 1).

The prerequisite for using loop snares is that the IVD should have a free edge to grasp. Sometimes the entrapped device lacks free edge, which is obtained using various dislodgement techniques using pigtail or double-curve catheter [3]. In one of our cases of unusually knotted temporary pacing lead, the free edge of the lead was lying in right atrium abutting against its wall. Hence, we chose needles eye snare, which has an angled nitinol loop along with additional threader passing through the loop that can be used in absence of free edge to grasp its distal part. In another case of malpositioned PDA closure device, free knob towards pulmonary end (where the delivery cable is attached) was lying encircled by the device struts which made passage of loop of macrosnare around the knob difficult. So, it was retrieved using microsnare (Figures $1 e, 1 f)$.

In our study, the procedural success rate was $90.9 \%$, which is consistent with previous studies (Table 2). On the other hand, no procedural complications were reported in our study, complications in the form of local site hematoma, arrhythmias, pulmonary embolism etc. have been reported in earlier studies (Table 2) but at a low frequency. Of note, percutaneous retrieval attempts with loop snares failed in one patient with migrated coronary stent lying at the left main ostium. Percutaneous retrieval of migrated coronary stents is difficult and should be 
carried out immediately to prevent complications such as stent-induced thrombosis, perforation, and death. In a series of 20 patients with coronary stent embolization reported by Eggebrecht et al., percutaneous retrieval attempted with gooseneck snares was successful in only $3(43 \%)$ out of 7 patients [24]. In such cases, deployment at migrated site is another option depending on stent characteristics (balloon or self-expandable) and the site of stent displacement. In our case, deployment was not feasible because the balloon and wire both had slipped out during stenting; hence, open surgical retrieval was required. According to Sheth et al., the angulations of left main artery with aorta make it difficult for loop snaring. Dormia baskets can be easily used in such cases which was not considered in our study [5].

The major disadvantage of using loop snares is their weaker gripping capabilities. Other reported devices like grasping forceps though have a stronger grip are more bulkier and traumatic while retrieval baskets are more difficult to manipulate especially in larger vessels [3]. However, Sheth et al. found dormia baskets to have greater degree of rotational capabilities and a wider diameter to grasp the foreign object with efficacy and safety comparable to the that of nitinol gooseneck snare [5]. Further, larger studies may be required to compare different types of retrieval devices.

\section{Study limitations}

This was a single centre, retrospective, observational study with relatively small number of patients without comparison with surgical arm or with other type of percutaneous retrieval.

\section{Conclusions}

Patients with complicated IVD, warranting retrieval, may have variable clinical presentation ranging from asymptomatic course to potentially serious ones. The underlying mechanisms or causes can be multifactorial and can be reduced by minimizing technical errors and proper patient and device selection. Percutaneous retrieval of such devices can be technically challenging but has higher success rate with minimal complications. It should be considered as first choice before surgical referral.

\section{References}

1. Thomas J, Sinclair-Smith B, Bloomfield D, et al. Non-surgical retrieval of a broken segment of steel spring guide from right atrium and inferior vena cava. Circulation. 30:106108(1964).

2. Tateishi M, Tomizawa Y. Intravascular foreign bodies: danger of unretrieved fragmented medical devices. J Artif Organs. 12:80-9(2009).

3. Koseoglu K, Parildar M, Oran I, et al. Retrieval of intravascular foreign bodies with goose neck snare. Eur J Radiol. 49:281-5(2004).
4. Gabelmann A, Kramer S, Gorich J. Percutaneous retrieval of lost or misplaced intravascular objects. Am J Roentgenol. 176:1509-13(2001).

5. Sheth R, Someshwar V, Warawdekar G. Percutaneous retrieval of misplaced intravascular foreign objects with the Dormia basket: an effective solution. Cardiovasc. Intervent Radiol. 30:48-53(2007).

6. Wolf F, Schernthaner RE, Dirisamer A, et al. Endovascular management of lost or misplaced intravascular objects: experiences of 12 years. Cardiovasc Intervent Radiol. 31:563-8(2008).

7. Bonvini RF, Rastan A, Sixt S, et al. Percutaneous retrieval of intravascular and intracardiac foreign bodies with a dedicated threedimensional snare: A 3year single center experience. Catheter Cardiovasc Interv. 74:939-45(2009).

8. Filho MLJM, Carnevale FC, Nasser F, et al. Endovascular techniques and procedures, methods for removal of intravascular foreign bodies. Rev. Bras Cir Cardiovasc. 25:202-8(2010).

9. Cahill AM, Ballah D, Hernandez P, et al. Percutaneous retrieval of intravascular venous foreign bodies in children. Pediatr Radiol. 42:24-31(2012).

10. Carroll MI, Ahanchi SS, Kim JH, et al. Endovascular foreign body retrieval. J Vasc Surg. 57:459-63(2013).

11. Baltazares-Lipp ME, Sarabia-Ortega B, Soto-González JI, et al. Intravascular foreign bodies: a single-institution experience and description of a novel modified percutaneous retrieval technique. Chin Med J. 131:484(2018).

12. Surhonne PS, Mahla H, Bhairappa S, et al. Successful retrieval of fractured pressure wire tip (FFR) by hybrid technique. $J$ Saudi Heart Assoc .27:118-22(2015).

13. Fisher RG, Ferreyro R. Evaluation of current techniques for nonsurgical removal of intravascular iatrogenic foreign bodies. Am J Roentgenol. 130:541-8(1978).

14. Richardson JD, Grover FL, Trinkle JK. Intravenous catheter emboli experience with 20 cases and collective review. Am J Surg. 128:722-7(1974).

15. Bernhardt LC, Wegner GP, Mendenhall JT. Intravenous catheter embolization to the pulmonary artery. Chest. 57:329-32(1970).

16. Schummer W, Schummer C, Gaser E, et al. Loss of the guidewire: mishap or blunder? Br J Anaesth.88:144-6(2002).

17. Nawale JM, Patil SN, Nalawade DD, et al. Successful percutaneous retrieval of unusually knotted temporary pacemaker lead. Indian Pacing Electrophysiol. J. 18:148-149(2018).

18. Fatehi A, Maadani M, Abdi S, et al. Frequent oversizing during amplatzer device deployment for percutaneous PDA closures. Iranian Heart Journal. 10:14-18(2009).

19. Colkesen AY, Baltali M, Acil T, et al. Coronary and systemic stent embolization during percutaneous coronary interventions: a single center experience. Int Heart J. 48:129-36(2007).

20. Nikolsky E, Gruberg L, Pechersky S, et al. Stent deployment failure: Reasons, implications, and shortand longterm outcomes. Catheter Cardiovasc Interv. 59:324-8(2003).

21. Laarman G, Muthusamy TS, Swart H, et al. Direct coronary stent implantation: safety, feasibility, and predictors of success of the strategy of direct coronary stent implantation. Catheter Cardiovasc Interv. 52:443-8(2001).

22. Schechter MA, O'Brien PJ, Cox MW. Retrieval of iatrogenic intravascular foreign bodies. J Vasc Surg. 57:276-81(2013).

23. Paulus BM, Fischell TA. Retrieval devices and techniques for the extraction of intravascular foreign bodies in the coronary arteries. J Interv Cardiol. 2010;23(3):271-6.

24. Eggebrecht H, Haude M, von Birgelen C, et al. Nonsurgical retrieval of embolized coronary stents. Catheter Cardiovasc Interv. 51:432-40(2000). 